\title{
PREPARATION OF A GLYCOPROTEIN FRACTION FROM POOLED HUMAN PLASMA AND ITS EVALUATION AS A SUBSTRATE FOR THE ASSAY OF CLOSTRIDIUM WELCHII (C. PERFRINGENS) NEURAMINIDASE
}

\author{
A. G. Fraser and J. K. Smith \\ Department of Bacteriology, Medical School, University of Edinburgh, Teviot Place, \\ Edinburgh EH8 $9 A G$, and \\ Scottish National Blood Transfusion Service, Protein Fractionation Centre, \\ Ellen's Glen Road, Edinburgh EH17 7 QT
}

\section{Plate XV}

NEURAMINIDASES (EC 3.2.1.18) are widely distributed in nature, being found in viruses, bacteria, protozoa and vertebrate tissues. In mammalian cells, neuraminidase appears to be a lysosomal enzyme (Taha and Carubelli, 1967). The role of neuraminidase in the replication and pathogenicity of myxoviruses has been much studied but remains unclear (Drzeniek, 1972). Neuraminidase is produced by a number of important bacterial pathogens, e.g., Clostridium welchii ( $C$. perfringens), Corynebacterium diphtheriae, Vibrio cholerae and Streptococcus pneumoniae, as well as by many harmless commensal organisms (Gottschalk and Bhargava, 1971). It has been suggested that neuraminidase production may be related to bacterial pathogenicity (Dewitt and Rowe, 1961; Collee, 1962 and 1965; Gadalla and Collee, 1968; Pardoe, 1970), but no positive correlation has so far been demonstrated (White and Mellanby, 1969; Drzeniek, Scharmann and Balke, 1972). In the course of investigations into the possible role of neuraminidase in infections caused by $C$. welchii, we found it necessary to develop a substrate for neuraminidase that is cheap and readily available in quantity.

Neuraminidases are usually assayed by measuring the release of $\mathrm{N}$-acetyl neuraminic acid (NANA) from a suitable glycoprotein, glycolipid or oligosaccharide substrate. The free NANA can be measured in the presence of excess substrate by the thiobarbituric-acid assays of Aminoff (1959 and 1961) or Warren (1959 and 1963). Cassidy, Jourdian and Roseman (1965 and 1966) recommend the use of $\mathrm{N}$-acetyl neuramin-lactose (NAN-lactose) prepared from bovine colostrum as substrate for the assay of $C$. welchii neuraminidase; this is widely used in neuraminidase assays, but commercially available preparations are very expensive, and it may be that the cost of NAN-lactose has been inhibiting further work on bacterial neuraminidases.

Popenoe and Drew (1957) prepared $\alpha_{1}$-acid glycoprotein (orosomucoid) from the urine of nephrotic patients and showed it to be a suitable substrate for $C$. welchii neuraminidase assays, and Hughes and Jeanloz (1964) used $\alpha_{1}$-acid glycoprotein prepared from human plasma as substrate in studies on pneumococcal neuraminidase. In early work on $C$. welchii neuraminidase in this laboratory (Collee, 1962 and 1965) hen egg-white was used as substrate.

Received 2 Aug. 1974; accepted 25 Sep. 1974. 
This was later replaced by human plasma (Gadalla and Collee, 1968), and Collee and Barr (1968) then described a simple method of preparing an unrefined glycoprotein fraction from $200-400 \mathrm{ml}$ of plasma from out-dated human blood by trichloracetic-acid precipitation. This human glycoprotein gave more reliable results than were obtainable by the use of whole plasma, and it has proved a very satisfactory substrate in this laboratory. However, the limited supply of starting material and the problems of scaling up certain stages such as dialysis would make it difficult to ensure a supply of closely standardised substrate during a prolonged investigation.

In this paper we describe a method of preparing large amounts of a glycoprotein fraction from pooled human plasma. The $\alpha_{1}$-acid glycoprotein is normally a waste product of large-scale plasma fractionation and a simple method of recovering it from the supernate from Cohn fraction $\mathrm{V}$ has been developed. It is considerably cheaper than commercially available NANlactose or pure $\alpha_{1}$-acid glycoprotein, does not carry the risk of transmitting serum hepatitis (hepatitis B) and is recommended as a substrate for routine use in neuraminidase assays.

\section{MATERIALS AND METHODS}

Substrate preparations. The following method was used to prepare NANA-rich glycoprotein (fraction VII) from the supernate of Cohn fraction V, obtained from approximately 1000 donations of plasma from out-dated blood, by Cohn method 6 (Cohn et al., 1946). A 120-litre volume of supernate from Cohn fraction V was titrated to $p \mathrm{H} 6.2$ and cold $\left(-25^{\circ} \mathrm{C}\right)$ ethanol added until the final concentration of ethanol was $70 \%(v / v)$; the temperature of the solution was lowered to $-10^{\circ} \mathrm{C}$ during the addition, and maintained for $24 \mathrm{~h}$. The resulting white precipitate was removed by continuous-flow centrifugation in a refrigerated Sharples Super-centrifuge at $20,000 \mathrm{~g}$ and a flow rate of 40 litres per $\mathrm{h}$. Approximately $700 \mathrm{~g}$ of moist precipitate was recovered and dissolved rapidly in 5 litres water. The solution was adjusted to $p \mathrm{H} 8.0$ with $2 \mathrm{M} \mathrm{NaOH}$ and pasteurised in a stainless steel vessel at $60^{\circ} \mathrm{C}$ for $10 \mathrm{~h}$. The solution was cooled, titrated to $p \mathrm{H} 5.0$ with dilute acetic acid and held frozen at $-20^{\circ} \mathrm{C}$. After some weeks it was thawed at $5^{\circ} \mathrm{C}$, centrifuged for $1 \mathrm{~h}$ at $4000 \mathrm{~g}$ to remove insoluble protein, and filtered rapidly through Green's $904 \frac{1}{2}$ fluted paper to remove floating lipoproteins. The solution was dispensed in vials, frozen and freeze-dried to a final vapour pressure of $13.33 \mathrm{~N} / \mathrm{m}^{2}(0.01$ torr $)$ at $20^{\circ} \mathrm{C}$.

Two such large-scale preparations were made, differing in minor details of scale, resolution volume and the volume dispensed for freeze-drying; there was no detectable difference between the batches. The results given in this paper were all obtained with the original batch, FVII(5). Each batch was very readily soluble in water, even in concentrations exceeding $50 \mathrm{mg}$ per $\mathrm{ml}$.

Electrophoresis. Cellulose-acetate electrophoresis was carried out on Sepraphore III medium (Gelman Instrument Co., Ann Arbor, Mich., USA) at $p \mathrm{H} \mathrm{8.6.} \mathrm{Strips} \mathrm{were} \mathrm{stained}$ for total protein (Ponceau S) and for glycoprotein (Kohn, 1968).

Total protein. Protein was estimated by a biuret method (Gornall, Bardawill and David, 1949); a copper-free control reagent was used to correct extinction readings for the opalescence of the glycoprotein preparations.

Electrolytes. $\mathrm{Na}^{+}$and $\mathrm{K}^{+}$were determined by flame photometry, chloride by a titrimetric method (Kit 830: Sigma Chemical Co. Ltd, Kingston upon Thames, Surrey) and $\mathrm{Ca}^{2}+$ by a fluorimetric method (Fingerhut, Poock and Miller, 1969).

Strain of C. welchii. This was a laboratory sub-strain (L2Ab) derived from a classical type-A strain originally obtained from Professor C. L. Oakley, School of Medicine, University of Leeds.

Culture media. Cultures, periodically prepared from lyophilised stock, were maintained 


\section{GLYCOPROTEIN SUBSTRATE FOR NEURAMINIDASE}

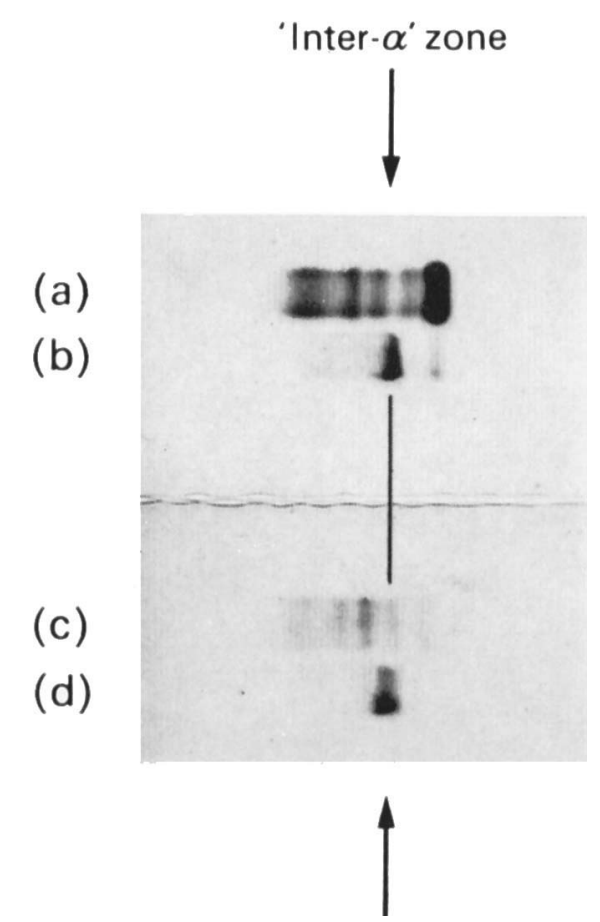

FIG. 1.-Separation of glycoprotein preparation FVII by cellulose-acetate electrophoresis. Samples $(a)$ and $(c)$, human serum; samples $(b)$ and $(d)$, fraction FVII. Strips $(a)$ and $(b)$ stained for total protein; strips $(c)$ and $(d)$ stained for glycoprotein. 
in tubes $(10 \mathrm{ml})$ of cooked-meat broth prepared as described by Cruickshank (1968, p. 757), but with Nutrient Broth (Oxoid, no. 2) replacing the peptone infusion broth.

The broth used for the production of neuraminidase contained ( $\mathrm{g}$ per litre): Proteose Peptone (Difco, code 0120) $50 \mathrm{~g}$ and $\mathrm{NaCl} 5 \mathrm{~g}$ and was adjusted to $\mathrm{pH} 7.0$. It was autoclaved at $121^{\circ} \mathrm{C}$ for $15 \mathrm{~min}$. and is referred to as $5 \%$ proteose peptone water (PPW5).

Anaerobic culture. Broth media were held in a steamer at $100^{\circ} \mathrm{C}$ for $30 \mathrm{~min}$. (pre-steamed) and promptly cooled to $37^{\circ} \mathrm{C}$ just before inoculation. BTL jars (Baird and Tatlock Ltd, Chadwell Heath, Essex) were used with room-temperature-active catalyst sachets supplied by BTL. The caps of bottles were loosened when they were put into anaerobic jars. Jars were filled with hydrogen and $10 \%(\mathrm{v} / \mathrm{v}) \mathrm{CO}_{2}$ according to the standardised procedure described by Collee, Rutter and Watt (1971).

Preparation of $C$. welchii neuraminidase. The test strain was inoculated into a tube of cooked-meat broth and incubated anaerobically at $37^{\circ} \mathrm{C}$ for $18 \mathrm{~h} ; 1 \mathrm{ml}$ of this culture was inoculated into $100 \mathrm{ml}$ of pre-steamed PPW5 broth and incubated anaerobically at $37^{\circ} \mathrm{C}$ for $48 \mathrm{~h} ; 20 \mathrm{ml}$ of this starter culture was used as inoculum for each of three $600-\mathrm{ml}(20-\mathrm{oz})$ narrow-mouthed Winchester bottles containing $500 \mathrm{ml}$ of pre-steamed PPW5 broth which were then incubated anaerobically at $37^{\circ} \mathrm{C}$ for $48 \mathrm{~h}$. The cultures were centrifuged at $1700 \mathrm{~g}$ for $1 \mathrm{~h}$ at $4^{\circ} \mathrm{C}$ and the culture supernates were pooled and stored at $4^{\circ} \mathrm{C}$. The pooled supernate was passed through a Seitz filter and the filtered supernate (P9) was stored at $-20^{\circ} \mathrm{C}$ for some months.

A $100-\mathrm{ml}$ sample of $P 9$ material was thawed and, after centrifugation $(2400 \mathrm{~g}$ for $30 \mathrm{~min}$. at $4^{\circ} \mathrm{C}$ ) to remove a slight precipitate, the supernate was dialysed at $4^{\circ} \mathrm{C}$ in $25 \mathrm{~mm}(1 \mathrm{in})$ Visking Cellophane tubing for $72 \mathrm{~h}$ against running tap water, and finally against a large excess of distilled water for $24 \mathrm{~h}$. This dialysed preparation (P9D2) had strong neuraminidase activity and was stored in $5-\mathrm{ml}$ volumes in " bijou " bottles at $-20^{\circ} \mathrm{C}$. No phospholipase-C ( $\alpha$-toxin) activity was demonstrable in tube tests with egg yolk and calcium-gelatin-saline (Holding and Collee, 1971).

Neuraminidase standard. Our preparations of neuraminidase were standardised by comparison with a commercially available preparation of chromatographically purified $C$. perfringens $(C$. welchii) neuraminidase (Sigma London Chemical Co. Ltd; neuraminidase, type VI, N3001); the batch had a declared activity of 1.1 unit per mg of solid with NANlactose as substrate and 0.58 unit per $\mathrm{mg}$ with bovine submaxillary mucin as substrate, 1 unit liberating $1.0 \mu$ mole NANA per min. at $p \mathrm{H} 5.0$ and $37^{\circ} \mathrm{C}$ from the test substrate.

Assay for $\mathrm{N}$-acetyl neuraminic acid. Aminoff's thiobarbituric-acid assay for free sialic acid as described by Cassidy et al. (1966) was followed. The reagents were: Reagent 1$0.025 \mathrm{M}$ periodic acid (Koch Light) in $0.25 \mathrm{M} \mathrm{H}_{2} \mathrm{SO}_{4}(\mathrm{BDH}$, Analar) at $p \mathrm{H} \mathrm{1.2}$; Reagent 2$\mathrm{NaAsO}_{2}(\mathrm{BDH}) 2 \%(\mathrm{w} / \mathrm{v})$ in $0.5 \mathrm{M} \mathrm{HCl}(\mathrm{BDH}$, Analar); Reagent 3-0.1 $\mathrm{M}$ 2-thiobarbituric acid (Koch Light) in $0.1 \mathrm{M} \mathrm{NaOH}(\mathrm{BDH}$, Analar) adjusted to $\mathrm{pH} 9.0$; and Reagent 4n-butanol containing $12 \mathrm{M} \mathrm{HCl} 5 \%(\mathrm{v} / \mathrm{v})$. Pure synthetic NANA (Koch Light) was used as a standard. In routine tests, $0.5-\mathrm{ml}$ samples were assayed in glass tubes $(125 \times 15 \mathrm{~mm})$. Spectrophotometric readings of the organic phase at a wavelength of $549 \mathrm{~nm}$ were made with 4-ml glass cuvettes (1-cm light path) in a Pye-Unicam SP 600 spectrophotometer. The reference cell contained a " reagent blank" prepared by taking $0.5 \mathrm{ml}$ distilled water through the assay procedure.

Assay for neuraminidase activity. For the standard test, $0.5 \mathrm{ml}$ of reaction mixture was prepared by adding the following volumes to glass tubes $(125 \times 15 \mathrm{~mm}): 0.1 \mathrm{ml}$ of enzyme preparation; $0.15 \mathrm{ml}$ of $0.1 \mathrm{M}$ sodium acetate buffer, $p \mathrm{H} 5.1$, (Cruickshank, 1968, p. 853); and $0.25 \mathrm{ml}$ of substrate FVII. Unless stated otherwise, dilutions of substrate or enzyme were made in acetate buffer, $p \mathrm{H} 5 \cdot 1$. Throughout the text the stated dilution of an enzyme preparation is that prepared for addition to the reaction mixture, but the concentration of substrate is normally given as the final concentration in the reaction mixture. Enzyme and substrate control tubes contained the equivalent volume of acetate buffer, $p \mathrm{H} 5 \cdot 1$, in place of the substrate and enzyme respectively. Reagents were normally held at room temperature before making the test mixtures, but were pre-warmed to $37^{\circ} \mathrm{C}$ when the period of incubation was to be less than $10 \mathrm{~min}$. After incubation for the appropriate period at $37^{\circ} \mathrm{C}$ in 
a water bath, reagent 1 was added to the mixture and the standard NANA assay was performed.

In studies of the time-course of the reaction with different concentrations of substrate and enzyme, standard tests were set up and incubated for graded periods of time. The timing of experiments was such that test periods of incubation ended simultaneously and all tests, including time-zero $\left(T_{0}\right)$ control tests, were assayed for NANA in a single batch. The $T_{0}$ controls were set up as follows: the standard assay volumes of enzyme, substrate and buffer, pre-cooled to $0^{\circ}-1^{\circ} \mathrm{C}$, were mixed in a tube held in an ice bath at $0^{\circ}-1^{\circ} \mathrm{C}$. The assay for NANA was begun immediately by adding reagent 1 and transferring the mixture to a water bath at $37^{\circ} \mathrm{C}$. As preliminary tests showed that the value for the $\mathrm{T}_{0}$ control was equal to the sum of separate enzyme and substrate controls performed at $\mathbf{T}_{0}$, and that the values for enzyme and substrate controls did not increase significantly during incubation for periods up to $24 \mathrm{~h}$, a $T_{0}$ control was used in place of separate enzyme and substrate controls for each test period.

Each test and control assay was performed in duplicate and an average value for the extinction at $549 \mathrm{~nm}$ was calculated. The test reading was corrected to give a value equivalent to the amount of NANA released from the substrate during the incubation period by subtraction of either the sum of separate enzyme- and substrate-control readings or the value for the $T_{0}$ control test. Reference assays of $10 \mu \mathrm{g}$ of pure NANA in $0.5 \mathrm{ml}$ of distilled water were performed with each batch of assays. The results of neuraminidase assays are expressed in terms of spectrophotometric readings and are not routinely converted into equivalent concentrations of NANA because the presence of constituents of the culture medium may influence the reading obtained in the assay for NANA (see Results).

Studies of the effect of $\mathrm{pH}$ on the neuraminidase assay. Sodium-acetate buffer solutions were prepared as described by Cruickshank $(1958, \mathrm{p} .853)$; the $p \mathrm{H}$ range was extended to give buffers of higher $p \mathrm{H}$ by the use of progressively smaller volumes of acetic acid and correspondingly larger volumes of sodium-acetate solution. In order to ensure adequate buffering, tests were performed in a greater volume than for standard neuraminidase assays. The total reaction-mixture volume of $1.0 \mathrm{ml}$ consisted of: $0.1 \mathrm{ml}$ of enzyme preparation P9D2 diluted 1 in 2 in distilled water; $0.65 \mathrm{ml}$ of the appropriate buffer; and $0.25 \mathrm{ml}$ of substrate FVII that had been diluted to $6.13 \mathrm{mg}$ per $\mathrm{ml}$ in distilled water. Separate enzyme and substrate controls were prepared at each $\mathrm{pH}$ value by replacing the substrate and enzyme respectively with the equivalent volume of the appropriate buffer. Tests and controls were incubated for $30 \mathrm{~min}$. at $37^{\circ} \mathrm{C}$ and then assayed for NANA by the standard method.

The starting $p \mathrm{H}$ values of this series of tests were measured during a separate experiment. With pre-cooled reagents, test mixtures were prepared in tubes held at $0^{\circ}-1^{\circ} \mathrm{C}$ in an ice bath and the $p \mathrm{H}$ of each mixture was measured immediately. Small samples were brought to $37^{\circ} \mathrm{C}$ in a Radiometer BMS2 system and the $p \mathrm{H}$ values at $37^{\circ} \mathrm{C}$ were promptly read on a linked Radiometer PHM 71 meter. The $p H$ values plotted for fig. 5 are these measured values for the initial $p \mathrm{H}$ of the reaction mixture. The tests were then incubated at $37^{\circ} \mathrm{C}$ for $30 \mathrm{~min}$. and the final $p \mathrm{H}$ again measured. In no case was there a deviation of more than $0.05 p \mathrm{H}$ unit during the assay period.

Tris-maleate buffer solutions were prepared as described by Diem and Lentner (1970); the $p \mathrm{H}$ range was extended to give buffers of lower $p \mathrm{H}$ by the use of progressively smaller quantities of $\mathrm{NaOH}$. Tests were performed by the same method as for the tests in acetate buffer and initial $p \mathrm{H}$ values were similarly determined.

Tests for effects of culture materials on the NANA assay. The effects of various preparations on the NANA assay were investigated by preparing test mixtures of $0.1 \mathrm{ml}$ of test substance, $0.15 \mathrm{ml}$ of sodium acetate buffer, $p H 5.1$, and $0.25 \mathrm{ml}$ of pure NANA in distilled water. Time-zero $\left(T_{0}\right)$ tests were prepared with pre-cooled reagents. Each test value was corrected by subtraction of the value obtained for control mixtures with buffer in place of NANA. Reference tubes containing only NANA in buffer were prepared by replacing the test substance with buffer, and each test result was compared with the appropriate reference value to show whether the test substance had interfered with the NANA assay.

When it was desired to demonstrate the extent of NANA breakdown that might occur during incubation under the conditions of the neuraminidase assay, tests and controls were 
also incubated at $37^{\circ} \mathrm{C}$ for the appropriate period before assaying for NANA. Experiments were timed so that test periods of incubation ended simultaneously and all tests, including $T_{0}$ tests, were assayed for NANA in a single batch. Any breakdown of NANA during incubation of a test mixture can be detected by comparing the corrected values for the incubated test and the $T_{0}$ test.

Time-course studies of the release of NANA from substrate by acid hydrolysis. Equal volumes $(0.7 \mathrm{ml})$ of a known concentration of $\mathrm{H}_{2} \mathrm{SO}_{4}$ and of substrate dissolved in distilled water were mixed in screw-capped " bijou " bottles and promptly put into a water bath at $80^{\circ} \mathrm{C}$. Reference bottles contained equal volumes of $\mathrm{H}_{2} \mathrm{SO}_{4}$ and of a solution of pure NANA in distilled water to demonstrate the extent of breakdown of NANA under the conditions of the test. The starting times were arranged so that the test periods of incubation ended simultaneously. The bottles were then rapidly cooled in two stages to $0^{\circ}-1^{\circ} \mathrm{C}$, duplicate $0.5-\mathrm{ml} \mathrm{samples} \mathrm{were} \mathrm{transferred} \mathrm{to} \mathrm{tubes} \mathrm{and} \mathrm{the} \mathrm{assay} \mathrm{for} \mathrm{NANA} \mathrm{was} \mathrm{immediately} \mathrm{performed.}$ Time-zero $\left(T_{0}\right)$ control tests were performed with chilled reagents, the mixture being held for only a few min. at $0^{\circ}-1^{\circ} \mathrm{C}$ before the assay for NANA. Test results were corrected by subtraction of the appropriate $\mathrm{T}_{0}$ control readings.

\section{RESULTS}

\section{Characterisation of the glycoprotein fraction FVII}

A vial of the glycoprotein fraction FVII prepared as described in the Methods section contained $18.4 \mathrm{mg}$ of dry powder. When this was dissolved in $1 \mathrm{ml}$ of water, the solution contained protein $12 \cdot 1 \mathrm{mg}, \mathrm{Na}^{+} 46 \mu$ mole, $\mathrm{K}^{+}<1 \mu$ mole, $\mathrm{Cl}^{-} 8 \mu$ mole and $\mathrm{Ca}^{2+} 0.42 \mu$ mole.

Cellulose-acetate electrophoresis of fraction FVII (fig. 1) separated it into a minor zone with the mobility of serum albumin and a major, rather broad, " inter- $\alpha$ " zone with a mobility intermediate between the $\alpha_{1}$ and $\alpha_{2}$ serum globulins. The albumin zone stained very poorly for glycoprotein while the " inter- $\alpha$ " zone stained quite intensely. Because the relative dye-binding characteristics of these proteins were unknown it was not possible to assess the proportion of the total protein migrating in each zone.

Electrophoretic and immunoelectrophoretic examination of fractions of FVII separated on Sephadex G-200 confirmed that the " inter- $\alpha$ " zone consisted of $\alpha_{1}$-acid glycoprotein, most of which had been polymerised during pasteurisation.

\section{Release of NANA from the substrate FVII by hydrolysis}

Release by acid hydrolysis. The total sialic acid present in fraction FVII was estimated by mild acid hydrolysis. When samples of it were heated at $80^{\circ} \mathrm{C}$ in $0.02 \mathrm{M} \mathrm{H}_{2} \mathrm{SO}_{4}$ (final concentration) for periods up to $2 \mathrm{~h}$ there was progressive release of NANA, reaching a steady maximum between 1 and $2 \mathrm{~h}$. When samples of NANA were similarly treated there was usually no significant breakdown and the extinction value obtained on assay of NANA incubated in acid for $2 \mathrm{~h}$ was used to convert the test value into the equivalent concentration of NANA. It was calculated that NANA constituted $4.7 \%$ of the dry weight of substrate FVII.

Release by C. welchii neuraminidase. The total amount of sialic acid that can be released from fraction FVII by $C$. welchii neuraminidase was determined 
by incubation of dilutions of it with undiluted enzyme preparation P9D2 under the conditions of the standard test for periods up to $2 \mathrm{~h}$. When reaction mixtures were incubated at $37^{\circ} \mathrm{C}$ in acetate buffer, $p \mathrm{H} 5 \cdot 1$, there was progressive release of NANA to a steady maximum after $80 \mathrm{~min}$; the same amount of NANA was released from our substrate by $C$. welchii neuraminidase as by the acid-hydrolysis procedure.

\section{Enzyme-substrate kinetic studies}

Initial velocity of neuraminidase reaction with varying concentrations of substrate. Enzyme preparation P9D2 was used at a dilution of 1 in 2 in the acetate buffer, $p \mathrm{H} 5 \cdot 1$, and a range of concentrations of substrate was prepared in the same buffer. Reaction mixtures were prepared for the standard neuraminidase assay and were incubated at $37^{\circ} \mathrm{C}$ for different periods of time before the NANA assay. Fig. 2 shows the plots of values for the amount of NANA released by the enzyme; these are linear for the first $10 \mathrm{~min}$. for all test concentrations of substrate, and a value for the initial reaction-velocity at each substrate concentration was derived from this portion of the graph.

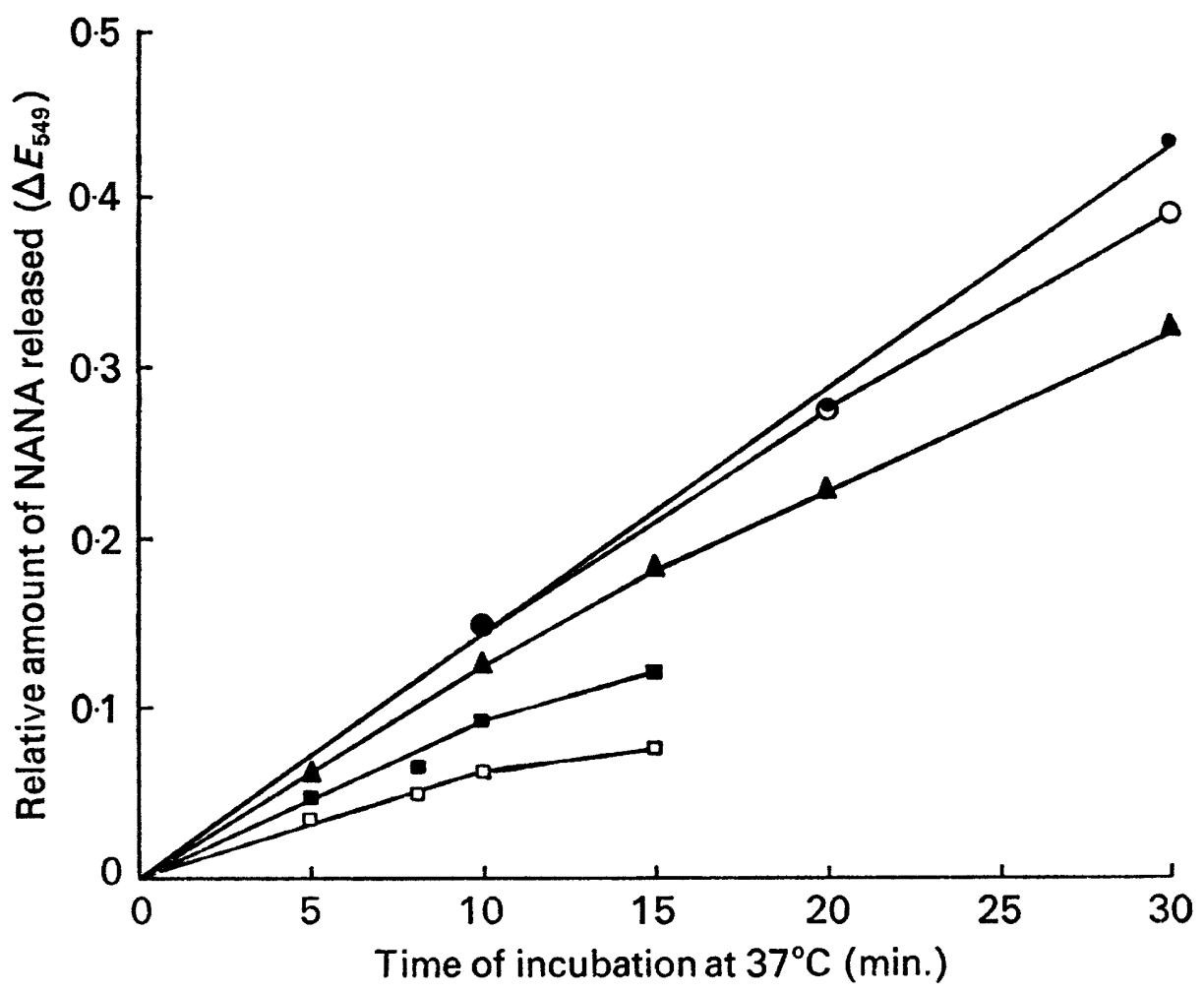

FIG. 2.-Velocity of neuraminidase reaction when a standard amount of enzyme P9D2 was incubated with graded concentrations of substrate at $p \mathbf{H} 5 \cdot 1$. Concentrations of substrate FVII (mg per ml of reaction mixture): $0,9 \cdot 2 ; O-O, 3.07 ; \Delta-\Delta, 0.92 ; \quad-0,0.23$; $\square-\square, 0 \cdot 12$. NANA $=\mathrm{N}$-acetyl neuraminic acid. 
Maximum velocity ( $V \max$ ) occurred at substrate concentrations of $c .3 \mathrm{mg}$ per $\mathrm{ml}$; the standard concentration of the original batch of substrate, FVII(5), used in subsequent experiments was $3.07 \mathrm{mg}$ per $\mathrm{ml}$. Vmax for this substrate was calculated to be $0.26 \mu \mathrm{g}$ NANA per min. and the $\mathrm{Km}$ value was $0.16 \mathrm{mg}$ per ml.

Initial velocity of neuraminidase reaction with varying concentrations of enzyme preparation. The final concentration of substrate FVII was $3.07 \mathrm{mg}$ per $\mathrm{ml}$ in the reaction mixture, and enzyme preparation P9D2 was diluted in acetate buffer, $p \mathrm{H} 5 \cdot 1$, to give test concentrations of $10,25,50,75$ and $100 \%$ $(\mathrm{v} / \mathrm{v})$. Standard neuraminidase assays were carried out with the different

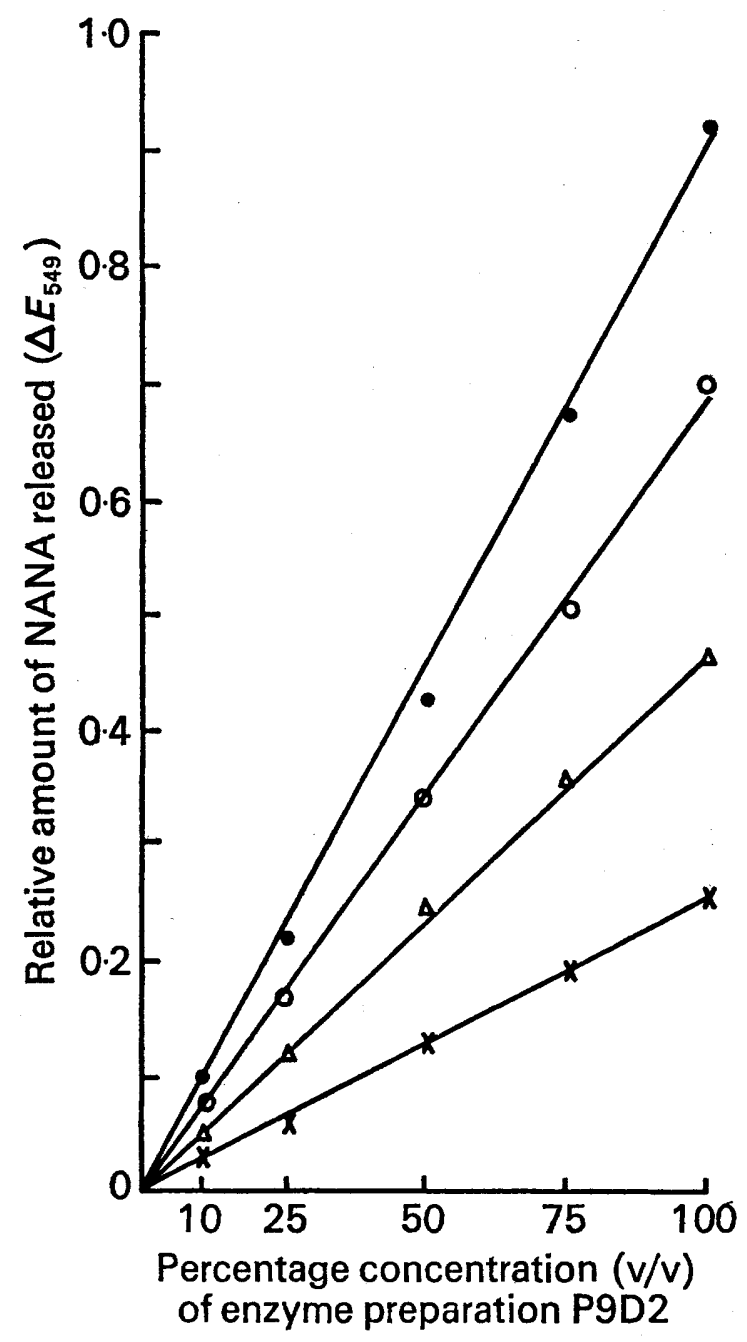

Fig. 3,-Amounts of NANA released at different times from a standard amount of substrate FVII by graded amounts of $C$. welchii neuraminidase. Period of incubation at $37^{\circ} \mathrm{C}$ (min.): $-10,4$ $\mathrm{O} \longrightarrow \mathrm{O}, 30 ; \triangle \stackrel{\triangle}{\longrightarrow}, 20 ; \times \longrightarrow \times, 10$. 


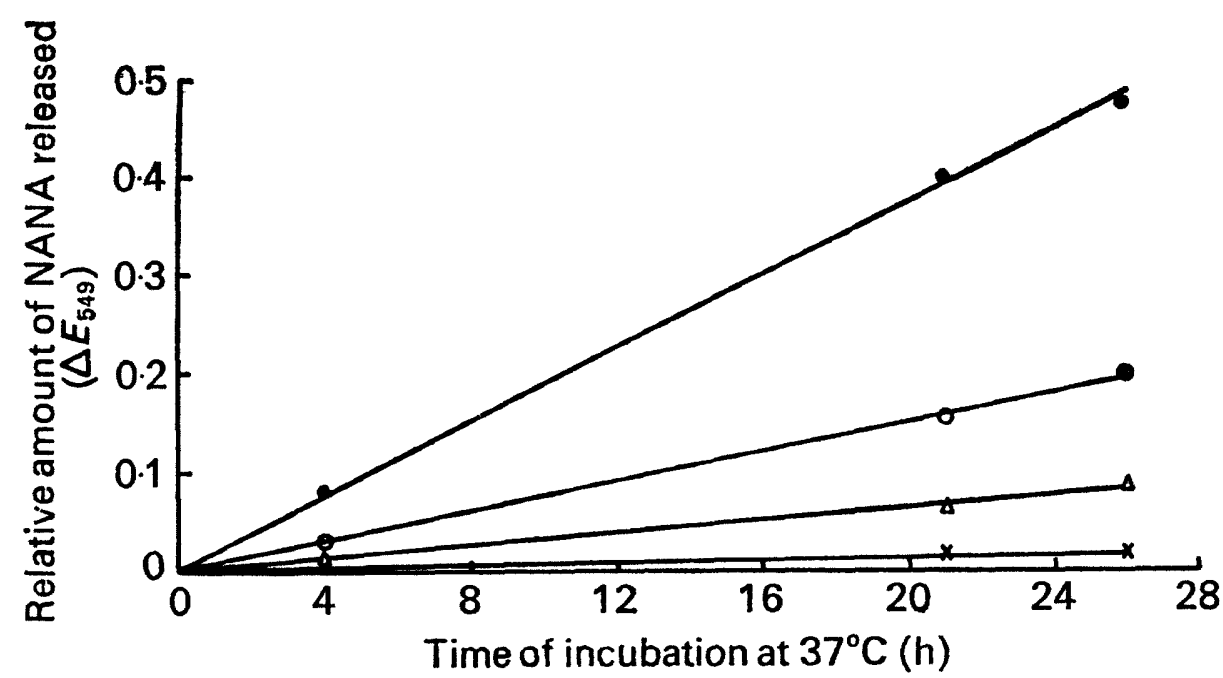

FIG. 4.-Release of NANA from substrate FVII by very low concentrations of neuraminidase during prolonged incubation at $37^{\circ} \mathrm{C}$ and $p H 5 \cdot 1$. Percentage concentration $(v / v)$ of enzyme preparation P9D2 added to reaction mixture: $-0,2 ; 0-0,1 ; \triangle \longrightarrow \triangle, 0.5 ; \times-\times, 0 \cdot 1$.

reaction mixtures incubated at $37^{\circ} \mathrm{C}$ for $10,20,30$ or $40 \mathrm{~min}$. before the NANA assay. In fig. 3 the rate of release of NANA is shown to be proportional to the concentration of the neuraminidase preparation when the reaction mixtures were incubated for periods of up to $40 \mathrm{~min}$. Thus, using a 15-min. assay, we could measure amounts of neuraminidase approximately $0 \cdot 1-3$ times that of the test P9D2 preparation. More concentrated neuraminidase preparations should be diluted before the assay so that the results fall into the reliable range.

Detection of release of NANA by small amounts of neuraminidase after prolonged incubation with substrate FVII. Experiments similar to that described above were used to follow the release of NANA from the same amount of substrate by lower concentrations of enzyme P9D2 during longer periods of incubation at $37^{\circ} \mathrm{C}$. Fig. 4 shows that the plot of the release of NANA from the substrate is linear for $26 \mathrm{~h}$ with suitable dilutions of enzyme P9D2 and that as little as $0.5 \%$ of the enzymatic activity can be reliably detected with a $24-\mathrm{h}$ test.

The effect of $p H$ on the neuraminidase assay. The results of the neuraminidase assay at different $p \mathrm{H}$ values in acetate buffer are shown in fig. 5(a). The plot of uncorrected results of duplicate tests shows a major peak of activity around $p \mathrm{H} 4.6$ and a subsidiary peak around $p \mathrm{H} \mathrm{5.6}$. The results of single-tube substrate-control assays are also plotted and these suggest that the main peak is actually at $p \mathrm{H} 4.7$. Fig. $5(b)$ shows the results of a similar experiment when tris-maleate buffers were used. There is a single peak of activity at $p \mathrm{H} \mathrm{5.7}$.

Direct readings of the initial and final $p \mathrm{H}$ of standard neuraminidase assays of dialysed and undialysed preparations of culture filtrate $\mathrm{P9}$ in acetate buffer, $p \mathrm{H} 5 \cdot 1$, showed that the initial $p \mathrm{H}$ of the reaction mixtures might be as high as $p \mathrm{H} 5 \cdot 45$, but did not vary during incubation. 


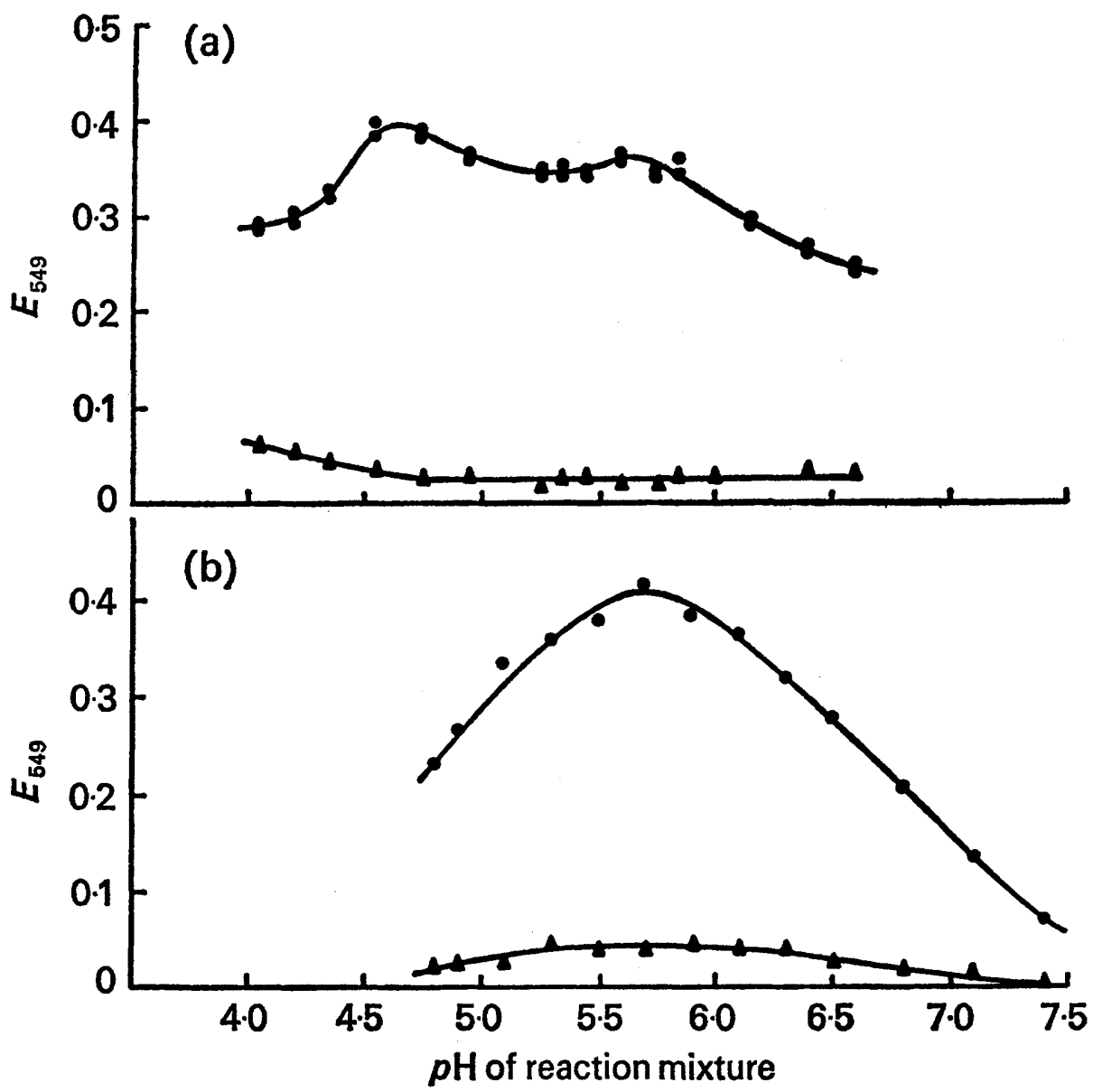

FIG. 5.-Effect of $p H$ and buffer system on the neuraminidase assay. Enzyme preparation P9D2 incubated with substrate FVII, $(a)$ in sodium-acetate buffers, $(b)$ in Tris-maleate buffers. Uncorrected test readings, - ; substrate-control readings, $\Lambda-\Lambda$. The enzyme control readings were very low and are not plotted.

\section{Effects of culture materials on the NANA assay}

When a sample of sterile PPW5 broth is taken through the NANA assay the formation of a chromogen with a peak absorption at $530 \mathrm{~nm}$ gives rise to significant absorption at $549 \mathrm{~nm}$. This gives rather high enzyme control values in assays of supernates of cultures in this medium, e.g. P9; the effect is very much reduced after dialysis.

When a standard amount of NANA is assayed with PPW5 culture supernate in the assay mixture, the corrected value (after subtraction of the enzymecontrol value) is sometimes markedly less than the value obtained in an equivalent assay devoid of culture supernate. The effect may also be seen with sterile PPW5 broth or other culture media; it is most marked with test mixtures that have high enzyme control readings (see below). 
Tests for destruction of NANA under the conditions of the neuraminidase assay

Samples of pure NANA $(10 \mu \mathrm{g})$ were incubated for periods up to $60 \mathrm{~min}$. with sterile PPW5 broth or with enzyme preparations P9 or P9D2 under conditions equivalent to those of the neuraminidase assay. The corrected value for the time-zero $\left(T_{0}\right)$ assay of each test mixture showed the extent of depression of the true value for NANA before the start of incubation at $37^{\circ} \mathrm{C}$. Sterile PPW5 broth reduced the assay reading by about $10 \%$ and the undialysed P9 preparation reduced it by about $25 \%$, whereas the dialysed preparation P9D2 produced less than $5 \%$ depression of the assay reading. There was no significant further depression of the assay values when the mixtures were incubated at $37^{\circ} \mathrm{C}$ for $60 \mathrm{~min}$., and there is therefore no evidence of significant $\mathrm{N}$-acyl neuraminic acid-aldolase (NAN-aldolase: $\mathrm{N}$-acyl neuraminate lyase, EC4.1.3.3) activity in either of the test enzyme preparations under the neuraminidase assay conditions. However, in view of the marked depression of the true NANA level by undialysed culture fluids, it is recommended that dialysed preparations be used where possible.

\section{Comparative studies on neuraminidase preparations}

Samples of Sigma neuraminidase in distilled water were compared in our assay with undiluted samples of undialysed enzyme preparation P9 and the dialysed preparation P9D2. The $0.1-\mathrm{ml}$ enzyme samples were incubated for $15 \mathrm{~min}$. at $37^{\circ} \mathrm{C}, p \mathrm{H} 5 \cdot 1$, with substrate FVII at a final concentration of 3.07 $\mathrm{mg}$ per $\mathrm{ml}$ in standard $0.5-\mathrm{ml}$ reaction mixtures. Separate enzyme and substrate controls were included and the results are shown in the table. The corrected spectrophotometric reading for undialysed enzyme P9, which has a high enzymecontrol reading, is a minimum value because interfering substances in the culture supernate must be assumed to have depressed the assay; the dialysed preparation has a satisfactorily low control value. The Sigma neuraminidase

TABLE

Results of 15-min. neuraminidase assay of Clostridium welchii enzyme preparations

\begin{tabular}{|c|c|c|c|c|}
\hline \multirow{2}{*}{$\begin{array}{l}\text { Test enzyme } \\
\text { preparation* }\end{array}$} & \multicolumn{3}{|c|}{ Spectrophotometric reading $\left(E_{549}\right) \dagger$} & \multirow{2}{*}{$\begin{array}{c}\text { Neuraminidase } \\
\text { activity } \S \\
\text { (milliunits per ml) }\end{array}$} \\
\hline & Test & $\begin{array}{l}\text { Enzyme } \\
\text { control }\end{array}$ & $\begin{array}{c}\text { Corrected } \\
\text { value } \ddagger\end{array}$ & \\
\hline $\begin{array}{l}\text { Sigma } \\
\text { P9 } \\
\text { P9D2 }\end{array}$ & $\begin{array}{l}0.614 \\
0.729 \\
0.454\end{array}$ & $\begin{array}{l}0.000 \\
0 \cdot 174 \\
0.015\end{array}$ & $\begin{array}{l}0.589 \\
0.530 \\
0.414\end{array}$ & $\begin{array}{l}27 \cdot 5 \\
24 \cdot 7 \\
19 \cdot 3\end{array}$ \\
\hline
\end{tabular}

\footnotetext{
* Sigma = chromatographically purified neuraminidase (Sigma Chemical Co., Ltd) at an initial concentration of $25 \mu \mathrm{g}$ per $\mathrm{ml}(0.1 \mathrm{ml}$ of this solution used in assay); $\mathrm{P} 9=$ undialysed supernate of culture of $C$. welchii strain L2Ab in PPW5 broth; P9D2 = dialysed sample of P9.

+ Average of duplicate readings.

$\ddagger$ Test reading corrected by subtraction of the sum of the values for the substrate control $(0.025)$ and the corresponding enzyme control.

$\S$ See text for method of calculation.
} 
was stated by the manufacturers to have a potency of $1 \cdot 1$ unit per mg of solid when tested with NAN-lactose as substrate; the concentration of Sigma neuraminidase in the test solution would thus have an activity of 27.5 milliunits per $\mathrm{ml}$. Separate tests similar to those described in the preceding section showed that this concentration of Sigma neuraminidase produced no depression of the assay value for NANA and no reduction in reading during incubation at $37^{\circ} \mathrm{C}$ for $15 \mathrm{~min}$. The corrected test value of $E_{549}=0.589$ for Sigma neuraminidase can thus be used to calculate the approximate potency of our neuraminidase preparations in terms of the standard unit based on the release of NANA from NAN-lactose.

The reference sample of $10 \mu \mathrm{g}$ of pure NANA gave a reading of 0.513 in this experiment. This allows calculation of the rate of NANA release from substrate FVII by the test amount $(2.5 \mu \mathrm{g})$ of Sigma neuraminidase; thus the potency of this batch of Sigma neuraminidase when acting on our substrate is approximately 1.0 unit per $\mathrm{mg}$ of solid, as compared with the stated $1 \cdot 1$ unit per $\mathrm{mg}$ with NAN-lactose or 0.58 unit per $\mathrm{mg}$ with bovine submaxillary mucin as substrate.

\section{DISCUSSION}

Most of the glycoprotein in our preparation was polymerised, probably as a result of the pasteurisation procedure (Spragg et al., 1969). This partial denaturation may facilitate hydrolysis of the substrate by neuraminidase. Although the risk of transmission of serum hepatitis by the fraction that we use is relatively small (Berg et al., 1972), it would be unwise to use the unpasteurised product in normal laboratory conditions. The glycoprotein fraction described by Gadalla and Collee (1968) is also liable to contain the agent of serum hepatitis, although the risks are low because plasma from only a few donors is used. If that preparation is being used, great care should be taken in handling the plasma and it should be pasteurised $\left(60^{\circ} \mathrm{C}\right.$ for $\left.10 \mathrm{~h}\right)$ at some stage during preparation.

The pasteurised FVII preparation is not an ideal substrate in that it does not consist of a pure, well-characterised substance, but it possesses certain compensating advantages. It is produced from a "waste" fraction with few manipulations and can therefore be made available comparatively cheaply. It is easy to prepare in standard form in large quantities and is very stable as a freeze-dried powder and even in solution at $4^{\circ} \mathrm{C}$. Its preparation does not involve the use of zinc salts (Bezkorovainy and Winzler, 1961), the residues of which might inhibit the action of enzymes on the substrate. The preparation has a low ionic content, the only residual buffer being a small amount of acetate, and its $p \mathrm{H}$ and ionic strength can therefore be easily adjusted in any incubation mixture. The content of readily hydrolysable NANA is high enough to avoid problems of viscosity or turbidity in the incubation mixture, and the level of free chromogen before hydrolysis is conveniently low. It must be borne in mind, however, that the preparation may contain a mixture of glycoproteins that might be hydrolysed at different rates by the same or by different enzymes. 
Cassidy et al. (1965) found that the NANA in $\alpha_{1}$-acid glycoprotein could be completely released by $C$. welchii neuraminidase and that the initial rate of release was slightly faster than the initial rate of release from bovine NAN-lactose. About $80 \%$ of the NAN-lactose in bovine colostrum is $\mathrm{N}$-acetyl neuramin- $(2 \rightarrow 3)$-lactose but the $(2 \rightarrow 6)$ isomer is also present (Schneir and Rafelson, 1966; Drzeniek, 1973). Viral neuraminidases may show a marked difference in ability to hydrolyse $(2 \rightarrow 3)$ and $(2 \rightarrow 6)$ linkages; both linkages are completely hydrolysed by $C$. welchii or $V$. cholerae neuraminidase although the rate of the reaction is rather slower with the $(2 \rightarrow 6)$ isomer (Cassidy et al., 1965; Drzeniek, 1967). In $\alpha_{1}$-acid glycoprotein, NANA is linked to the carbohydrate side chains by both $(2 \rightarrow 3)$ and $(2 \rightarrow 6)$ linkages (Drzeniek, 1973).

A variety of acyl groups are found on the neuraminic acid of naturally occurring compounds. Since the Warren and Aminoff assays give lower readings for $\mathbf{N}$-glycolyl than for N-acetyl derivatives (Warren, 1959; Aminoff, 1961; Drzeniek, 1972), it is desirable that a substrate should contain only the $\mathrm{N}$-acetyl derivatives. Human $\alpha_{1}$-acid glycoprotein, unlike that from many other species, does not contain N-glycolyl neuraminic acid (see Jeanloz, 1972). It has generally been considered that human tissues contain only the $\mathrm{N}$-acetyl derivatives (Gottschalk, 1960), but Walkowiak, Kedzierska and Starzynski (1968) have reported a trace of $\mathrm{N}$-glycolyl neuraminic acid in human serum.

The $\alpha_{1}$-acid glycoprotein prepared from nephrotic urine was shown to be a good substrate for assays of $C$. welchii neuraminidase by Popenoe and Drew (1957) and we have now shown that our FVII preparation from human plasma is also a good substrate. The calculations based on the activity of purified $C$. welchii (Sigma) neuraminidase in our assay sugggest that the initial velocity of release of NANA from our substrate is comparable to that from bovine NAN-lactose. The assay procedure that we describe allows accurate measurement of a wide range of concentrations of the enzyme. Even very small amounts of neuraminidase activity can be detected with confidence by prolonging the period of incubation to $24 \mathrm{~h}$, and this is of value when it is important to demonstrate the absence of neuraminidase, e.g. in comparative studies of neuraminidase production by different strains of $C$. welchii (Fraser and Collee, 1975).

Varying the $p \mathrm{H}$ of our assay in tris-maleate buffer produced a plot of activity that showed a simple curve with a clear-cut optimum at about $p \mathbf{H} 5.7$. When sodium-acetate buffer was used, the curve was more complex with the main peak at about $p \mathrm{H} 4.7$ and a subsidiary peak at about $p \mathrm{H} \mathrm{5.6}$. The $p \mathrm{H}$ optimum for the activity of a particular neuraminidase may vary considerably when tested with different substrates (Rafelson, Schneir and Wilson, 1963) or in the presence of different buffer ions (Cassidy et al., 1965). Burton (1963) found a sharp

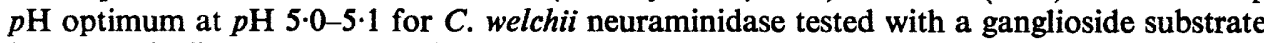
in acetate buffer. Popenoe and Drew (1957) found the optimum to be $p \mathrm{H} \mathrm{5.0-5.5}$ in acetate buffer with $\alpha_{1}$-acid glycoprotein as substrate. Cassidy et al. (1965) found the optimum for C. welchii neuraminidase acting on bovine NAN-lactose to be approximately $p \mathrm{H} 5.6$ in tris-maleate or in citrate-phosphate buffers but between $p \mathrm{H} 4.0$ and 4.8 in acetate buffer. Our finding of a subsidiary peak around $p \mathrm{H} 5.6$ in acetate buffer with fraction FVII as substrate may reflect a heterogeneity of NANA linkages in the preparation, perhaps due to the presence of a mixture of glycoproteins or to alterations in glycoproteins produced by pasteurisation; it might also be due to different $p \mathrm{H}$ optima for the hydrolysis of $(2 \rightarrow 3)$ and $(2 \rightarrow 6)$ linkages, as was found for influenza-virus neuraminidase by Schneir and Rafelson (1966). Cassidy et al. (1966) recommend that the assay of C. welchii neuraminidase with NAN-lactose as substrate should be performed in potassium-acetate buffer at $p \mathrm{H} 4 \cdot 5$. When the assay is performed with FVII substrate and sodium acetate buffer at $p \mathrm{H} 5 \cdot 1$, the results fall on the high plateau between the two peaks of activity; for assays performed in trismaleate buffer the $p \mathrm{H}$ should be $p \mathrm{H} 5.7$ with this substrate. $C$. welchii neuraminidase does not require added $\mathrm{Ca}^{2}+$ (Cassidy et al., 1965); optimum buffer and ion conditions may differ when fraction FVII is used as substrate for enzymes derived from other organisms or from viruses.

\section{C. welchii produces neuraminidase well when grown in PPW5 broth,}


and the culture filtrate is a good source of neuraminidase. When undialysed culture filtrate is assayed, there is a rather high control value in the neuraminidase assay, and we have found that there may be a significant depression of the assay value for pure NANA. Different batches of PPW5 broth vary in the extent to which they depress the NANA assay and the $25 \%$ depression produced by our culture filtrate $\mathbf{P 9}$ is the most marked that we have observed. The effect is minimal with dialysed preparations, e.g. P9D2, or with purified (Sigma) neuraminidase. We have not investigated the mechanism of the depression of the NANA assay by dialysable components of the PPW5 broth; a number of substances are known to interfere with the thiobarbituric acid assay for NANA (see Tuppy and Gottschalk, 1972) and this should be taken into account when neuraminidase assays are performed on unpurified enzyme preparations.

C. welchii also produces $\mathrm{N}$-acyl neuraminic acid-aldolase (NAN-aldolase), an enzyme that hydrolyses NANA to $\mathrm{N}$-acetyl mannosamine and pyruvate (Comb and Roseman, 1960). This enzyme is normally intracellular, but Popenoe and Drew (1957) found a little activity in culture filtrates of $C$. welchii; however, our enzyme preparations did not reduce the assay value for NANA during incubation under conditions equivalent to those of the neuraminidase assay.

Neuraminidase activity is commonly expressed in terms of units; 1 unit liberates $1 \mu$ mole of NANA per min. from the substrate at $37^{\circ} \mathrm{C}$ in a suitable buffer at the optimum $p \mathrm{H}$ (Drzeniek, 1972). It seems desirable that neuraminidase activities should be stated in standard units measured with NAN$(2 \rightarrow 3)$-lactose as substrate and we have refrained from expressing our results in terms of units measured with our substrate, though we have related the potencies of our test enzyme preparations to a commercially available reference preparation (Sigma neuraminidase). We have shown that our product is a good substrate for routine use in assays of neuraminidase from $C$. welchii, and preliminary experiments suggest that it should also prove valuable in studies of neuraminidase from other sources, e.g. Corynebacterium diphtheriae (personal communication, Dr D. C. Edwards and Mrs Karen Fidgen, Wellcome Research Laboratories, Beckenham, 1972), V. cholerae, influenza virus and Newcastle disease virus. It is hoped that the availability of this substrate at reasonable cost will encourage further studies on bacterial neuraminidases.

\section{SUMMARY}

A glycoprotein fraction (fraction VII) suitable for use as a substrate in assays of microbial neuraminidase was prepared from pooled human plasma. It is pasteurised during preparation to eliminate the risk of transmission of serum hepatitis. This results in polymerisation of some of the $\alpha_{1}$-acid glycoprotein, but fraction VII is shown to be an excellent substrate for the neuraminidase of Clostridium welchii (C. perfringens). A sensitive assay procedure is described. A number of factors may interfere with the measurement of NANA released by the action of microbial neuraminidase and procedures 
are described for evaluation of this problem. Fraction VII is easy to prepare, cheap and available in standard form in large amounts (inquiries should be addressed to J. K. S.); it is recommended for routine use as a convenient substrate for neuraminidase assays.

We thank Mr Robert Brown and his colleagues in the Department of Bacteriology for skilled technical assistance, and Mr John Cowie, Medical Renal Unit, Royal Infirmary, Edinburgh, for his help with critical $p \mathrm{H}$ measurements. We also thank Professor J. G. Collee, Department of Bacteriology, for his support and encouragement, and the Scottish National Blood Transfusion Association for the use of plasma fractions from voluntary blood donations.

\section{REFERENCES}

Aminoff, D. 1959. The determination of free sialic acid in the presence of the bound compound. Virology, 7, 355.

AmINofF, D. 1961. Methods for the quantitative estimation of $\mathbf{N}$-acetylneuraminic acid and their application to hydrolysates of sialomucoids. Biochem. J., 81, 384.

Berg, R., Bjorling, H., Bernsten, K. and Espmark, A. 1972. Recovery of Australia antigen from human plasma products separated by a modified Cohn fractionation. Vox Sang., 22, 1.

Bezkorovainy, A. AND WinzLer, R. J. 1961. Isolation and characterisation of an acidic $\alpha_{2}$-glycoprotein. Biochim. biophys. Acta, 49, 559.

BURTON, R. M. 1963. The action of neuraminidase from Clostridium perfringens on gangliosides. J. Neurochem., 10, 503.

Cassidy, J. T., Jourdian, G. W. And Roseman, S. 1965. The sialic acids. VI. Purification and properties of sialidase from Clostridium perfringens. J. biol. Chem., 240, 3501.

Cassidy, J. T., Jourdian, G. W. And Roseman, S. 1966. Sialidase from Clostridium perfringens. In Methods in enzymology, edited by S. P. Colowick and N. O. Kaplan, New York and London, vol. 8, p. 680.

Cohn, E. J., Strong, L. E., Hughes, W. L. Jr, Mulford, D. J., Ashworth, J. N., Melin, M. and TAYLOR, H. L. 1946. Preparation and properties of serum and plasma proteins. IV. A system for the separation into fractions of the protein and lipoprotein components of biological tissues and fluids. J. Am. chem. Soc., 68, 459.

COLLEE, J. G. 1962. The nature and properties of the haemagglutinin of Clostridium welchii and its relationship to the neuraminidase and other diffusible products of the organism. M.D. Thesis, University of Edinburgh.

COLleE, J. G. 1965. The relationship of the haemagglutinin of Clostridium welchii to the neuraminidase and other soluble products of the organism. J. Path. Bact., 90, 13.

Collee, J. G. AND BARR, W. A. 1968. Note on substrates for neuraminidase. J. Path. Bact., 96, 184.

Collee, J. G., Rutter, J. M. AND WATt, B. 1971. The significantly viable particle: a study of the subculture of an exacting sporing anaerobe. J. med. Microbiol., 4, 271.

Comb, D. G. AND Roseman, S. 1960 . The sialic acids. I. The structure and enzymatic synthesis of N-acetylneuraminic acid. J. biol. Chem., 235, 2529.

Cruickshank, R. 1968. Medical microbiology, 11 th ed., revised reprint, Edinburgh and London.

Dewrt, C. W. and Rowe, J. A. 1961. Sialic acids (N,7-O-diacetylneuraminic acid and $\mathrm{N}$-acetylneuraminic acid) in Escherichia coli. I. Isolation and identification. J. Bact., 82, 838 .

DIem, K. AND LentNer, C. 1970. Documenta Geigy: scientific tables, 7th ed., Basle, p. 280.

DrzenIEK, R. 1967. Differences in splitting capacity of virus and Vibrio cholerae neuraminidases on sialic acid type substrates. Biochem. biophys. Res. Commun., 26, 631.

DrZENIEK, R. 1972. Viral and bacterial neuraminidases. Curr. Top. Microbiol. Immunol., $59,35$. 
DrzenIEK, R. 1973. Substrate specificity of neuraminidases. Histochem. J., 5, 271.

DrZeniek, R., ScharmanN, W. AND BALKe, E. 1972. Neuraminidase and N-acetylneuraminate pyruvate-lyase of Pasteurella multocida. J. gen. Microbiol., 72, 357.

Fingerhut, B., Poock, A. AND Miller, H. 1969. Automated fluorometric method for the determination of serum calcium. Clin. Chem., 15, 870.

Fraser, A. G. AND Collee, J. G. 1975. The production of neuraminidase by food-poisoning strains of Clostridium welchii (C. perfringens). J. med. Microbiol., 8, 251.

Gadalla, M. S. A. AND Collee, J. G. 1968. The relationship of the neuraminidase of Clostridium septicum to the haemagglutinin and other soluble products of the organism. J. Path. Bact., 96, 169.

Gornall, A. G., Bardawill, C. J. ANd David, M. M. 1949. Determination of serum proteins by means of the biuret reaction. J. biol. Chem., 177, 751 .

GotTSCHalK, A. 1960. The chemistry and biology of sialic acids and related substances, Cambridge, p. 31.

GotTschalk, A. AND Bhargava, A. S. 1971. Neuraminidases. In The enzymes, 3rd ed., edited by P. D. Boyer, New York and London, vol. 5, p. 321.

Holding, A. J. ANd Collee, J. G. 1971. Routine biochemical tests. In Methods in microbiology, edited by J. R. Norris and D. W. Ribbons, London and New York, vol. 6A, p. 18.

Hughes, R. C. and Jeanloz, R. W. 1964. The extracellular glycosidases of Diplococcus pneumoniae. I. Purification and properties of a neuraminidase and a $\beta$-galactosidase. Action on the $\alpha_{1}$-acid glycoprotein of human plasma. Biochemistry, N.Y., 3, 1535.

JEANLOZ, R. W. 1972. $\alpha_{1}$-Acid glycoprotein. In Glycoproteins, their composition, structure and function, 2nd ed., edited by A. Gottschalk, Amsterdam, London and New York, part A, p. 565.

KoHN, J. 1968. Cellulose acetate electrophoresis and immuno-diffusion techniques. In Chromatographic and electrophoretic techniques, 2 nd ed., edited by I. Smith, London, vol. 2, p. 84.

PARdoE, G. I. 1970. The inducible neuraminidase (N-acyl-neuraminyl hydrolase EC 3.2.1.18) of Klebsiella aerogenes NCIB 9479. Pathologia Microbiol., 35, 361.

Popenoe, E. A. AND DREw, R. M. 1957. The action of an enzyme of Clostridium perfringens on orosomucoid. J. biol. Chem., 228, 673.

Rafelson, M. E. JR, SChNeIR, M. and Wilson, V. W. JR. 1963. Studies on the neuraminidase of influenza virus. II. Additional properties of the enzymes from the Asian and PR8 strains. Archs Biochem. Biophys., 103, 424.

SCHNEIR, M. L. AND RAFELSON, M. E. JR. 1966. Isolation and characterisation of two structural isomers of $\mathrm{N}$-acetylneuraminyllactose from bovine colostrum. Biochim. biophys. Acta, 130, 1.

Spragg, S. P., Halsall, H. B., Flewett, T. H. and Barclay, G. R. 1969. The thermal polymerisation of orosomucoid. Biochem. J., 111, 345.

TAHA, B. H. AND CARUBELli, R. 1967. Mammalian neuraminidase: intracellular distribution and changes of enzyme activity during lactation. Archs Biochem. Biophys., 119, 55.

TUPPY, H. AND GoTTSCHALK, A. 1972. The structure of sialic acids and their quantitation. In Glycoproteins, their composition, structure and function, 2nd ed., edited by A. Gottschalk, Amsterdam, London and New York, part A, p. 403.

WALKowIAK, H., KEDZIERSKA, B. AND STARZYNSKI, W. 1968. Horizontal circular chromatography of sialic acids from serum of certain mammal species. Bull. Acad. pol. Sci., Ser. Sci. biol., 16, 97.

WARREN, L. 1959. The thiobarbituric acid assay of sialic acids. J. biol. Chem., 234, 1971.

WARREN, L. 1963. Thiobarbituric acid assay of sialic acids. In Methods in enzymology, edited by S. P. Colowick and N. O. Kaplan, New York and London, vol. 6, p. 463.

White, A. B. AND MellanBY, J. 1969. The separation of neuraminidase activity from other pathological activities of a culture filtrate of Clostridium sordellii CN 3903. J. gen. Microbiol., 56, 137. 